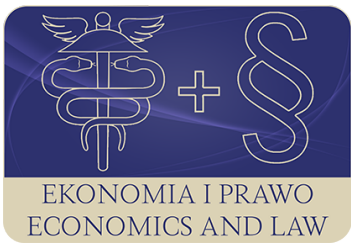

EKONOMIA I PRAWO. ECONOMICS AND LAW

Volume 15, Issue 4, December 2016

p-ISSN 1898-2255, e-ISSN 2392-1625

www.economicsandlaw.pl

ORIGINAL ARTICLE

received 13.10.2015; revised 18.06.2016; accepted 31.12.2016

Citation: Piątek, D. (2016). Institutions and economic growth in transition countries - new experiences and implications from financial crisis 2007-2010 (Part 2). Ekonomia i Prawo. Ecomomics and Law, 15(4): 527-545. doi:10.12775/EiP.2016.036.

\title{
Institutions and economic growth in transition countries - new experiences and implications from financial crisis 2007-2010 (Part 2)
}

\author{
DAWID PIĄTEK \\ Poznań University of Economics, Faculty of Economics, Department of Macroeconomics \\ and Development Studies, al. Niepodległości 10, 61-875 Poznań, Poland \\ $\square$ dawid.piatek@ue.poznan.pl.
}

\begin{abstract}
Motivation: Cross-country growth regressions indicate that institutions are important for growth. Some institutions are created, protected and enforced by the government they are the institutions of state. The most important for economic growth are: economic

freedom and protection of property rights, political freedom (or democracy), quality of governance and the rule of law. Institutions are especially important in transition countries. Two questions arise: were institutions important for economic growth in transition countries during the financial crisis? What happened to the institutions of state during the financial crisis?

Aim: The aim of the second part of this article is to verify two hypothesis about institutions and economic growth in transition countries, which were put forward in the first part of this article. In order to estimate the relationship between institutions and economic growth in transition countries during the crisis, a cross-sectional regression was conducted. Additionally the Granger causality test was conducted.

Results: The obtained results indicate that during the recession, in countries were before the crisis the institutions were worse, the pace of the economic growth was greater (hypothesis 1 should be rejected). In order to verify hypothesis 2 that the economic growth contributes to changes in state institutions in such a way that the faster the pace of growth the greater the improvement in state institutions a cross-sectional regression was used and the Granger causality test was conducted. Obtained results do not confirm the hy-
\end{abstract}


pothesis 2 . The estimates of parameters were in line with the expectations but statistically insignificant.

Keywords: institutions; economic growth; transition countries; financial crisis

JEL: D02; O11; P30

\section{Introduction}

The changes that took place after 1989 in the countries of Central-Eastern Europe were not only political but also economic. But above all, the post-socialist transition was an institutional change - all basic types of institutions: markets, firms, and institutions of state had to be changed. An institutional change constitutes, alongside macroeconomic stabilization and microeconomic liberalization, a key element of economic transition. According to the literature institutions matter in transition economies and are one of the main determinants of the economic growth and economic success of these countries.

This paper is an attempt to answer the question: how the institutions of state affect economic growth in transition countries and if the economic situation (the pace of the economic growth) has an impact on institutions during the financial crisis. In the first part two hypotheses were formulated. Hypothesis 1: quality of state institutions from before the crisis had a positive influence on the economic growth during the crisis. Hypothesis 2: the economic growth influences the changes of state institutions in such a way that the faster the growth the faster the improvement of state institutions, whereas a slow growth (recession) may lead to deteriorating of institutions. In this part those hypothesis are verified.

The paper is structured as follows: the next section presents the empirical data. Two further sections present a model and test the formulated hypotheses. The final section presents conclusions.

\section{Data}

The empirical analysis was conducted for 25 post-socialist countries for 20072012. Due to significant lack of data or only recent regaining of independence, the analysis does not include such countries as: Bosnia and Herzegovina, Montenegro, Kosovo and Serbia. The sources of variables and their short descriptions are presented in the in table 1, while their descriptive statistics are shown in table 2.

As a measure of economic growth, a rate of yearly change in the real GDP per capita was used ${ }^{1}$. In order to characterise the institutions of state and the changes which they underwent in transition countries, indicators concerning three main state institutions, i.e. political and economic freedom, and quality of governance,

\footnotetext{
${ }^{1}$ It was calculated as: $Y_{t} / Y_{t-1}$, where $Y_{t}$ denotes real GDP per capita and $t$ denotes time.
} 
were applied ${ }^{2}$. As a measure of the political freedom, the arithmetic average of the Freedom House's Political Rights index and the Freedom House's Civil Rights index was used (with values from 1 to 7; the lower the value the greater the political freedom). In order to measure the economic freedom, the Index of Economic Freedom published by the Heritage Foundation was used (with values from 0 to 100 , where 100 refers to the maximum scope of economic freedom). Apart from that, the study employed also the indicators of quality of governance published by the World Bank in a series of reports entitled 'Governance Matters', which are made available in the database of Worldwide Government Indicators (the maximum value of each of the indicators is 2,5 and the minimum one -2,5; the greater the value, the better the quality of governance). The indicators include: Voice and Accountability (VA), Political Stability and Absence of Violence/Terrorism (PS), Government Effectiveness (GE), Regulatory Quality (RQ), Rule of Law (RL), and Control of Corruption (CC).

The analysed transition countries were divided into three groups according to the criterion of the quality of state institutions before the crisis of 2002-2006 (chart 1). The groups were:

- countries with good state institutions (democratic market economies): Bulgaria, Croatia, Czech Republic, Estonia, Hungary, Latvia, Lithuania, Poland, Romania, Slovakia, Slovenia;

- countries with bad state institutions (authoritarian, no economic freedom): Armenia, Azerbaijan, Belarus, Kazakhstan, Kyrgyzstan, Russia, Tajikistan, Turkmenistan, Uzbekistan;

- countries with not so good state institutions: Albania, Former Yugoslav Republic of Macedonia (FYROM), Georgia, Moldavia, Ukraine.

It must be noticed that countries with good state institutions are those which belong to the EU, and as such having strong economic ties with other EU countries, as well as countries with no significant resources of crude oil and gas. In contrast, countries with bad state institutions are countries little economically integrated with the EU and often rich in crude oil and natural gas. At the same time, as it was previously noticed, this division is based also on changes in the GDP in 2007-2010. The effects of the crisis were felt in the first group much more keenly than in the second (chart 2). As stated in Hypothesis 1, we expected the opposite.

Changes in the institutions of state in the period of crisis and after it are presented in chart 3.

It is difficult to indicate any clear tendencies. Among the countries with good institutions, their significant improvement was noticeable in Poland, whereas in Latvia state institutions deteriorated visibly. Among the countries with bad institutions it is difficult to indicate those which experience either significant improvement or deterioration of their state institutions. This may be done only in the case of the countries with not so good institutions - a significant im-

2 A similar set of indicators to characterize the institutional environment in the CIS countries is used by Schweickert et al. (2008). 
provement was noticeable in Georgia and a significant deterioration was visible in Ukraine.

\section{Relation between pre-crisis institutions and economic growth during the financial crisis}

In order to verify hypothesis 1 , according to which the impact of the quality of institutions of state from before the crisis on the economic growth during the crisis is positive, a cross-sectional regression was applied between the geometric mean of the economic growth in 2007-2010, as a dependent variable, and an average indicator of the selected state institutions in 2002-2006. This relationship is presented in chart 4.

The data presented in chart 4 suggest that the relationship between institutions and economic growth in transition countries during the crisis was negative. Nevertheless, looking at chart 4 from the perspective of particular groups of countries, we can see that this dependency concerns mostly countries with bad institutions. In order to estimate this relationship, a cross-sectional regression was conducted, based on the following equation:

$$
\Delta y=\alpha+\beta \cdot \text { inst }+\varepsilon,
$$

where:

$\Delta y$ - the average GDP per capita growth in 2007-2010;

$\alpha, \beta$ - estimated parameters;

inst - state institution (average indicator in 2002-2006);

$\varepsilon$ - error term.

The results of this calculation are presented in table 3.

Although the results presented above indicate that the relationship between state institutions before the financial crisis and the economic growth in the period of the crisis was negative, they must be interpreted with caution. What they actually show is rather that other factors had a more significant impact on the severity of the recession in a given country, among them economic and financial ties with EU countries, and state institutions were not particularly relevant to the development of the crisis. This issue requires further research. Nevertheless, the obtained results of the cross-sectional regression enable us to reject hypothesis $1\left(H_{1}\right)$.

In order to confirm the obtained results, the Granger causality test was additionally conducted. It can be said that process $X_{t}$ is causing $Y_{t}$ in the Granger (1969, p. 428) sense, if it is possible to predict $Y_{t}$ better than if the information apart from $X_{t}$ had been used.

In this model, the following null hypothesis is tested: state institutions were not the causes in the Granger sense of the GDP growth in post-socialist countries during the financial crisis period. 
The verification of this hypothesis was based on the set of the following two equations $^{3}$ :

$$
\begin{aligned}
& \Delta y_{i, t}=A_{0} D_{t}+\sum_{j=1}^{q} \gamma_{j} \Delta y_{i, t-j}+\alpha_{i}+\varepsilon_{i, t}, \\
& \Delta y_{i, t}=A_{0} D_{t}+\sum_{j=1}^{q} \gamma_{j} \Delta y_{i, t-j}+\sum_{j=1}^{q} \beta_{j} \text { inst }_{i, t-j}+\alpha_{i}+\mu_{i, t},
\end{aligned}
$$

where:

$i$ - country;

$t$ - time;

$\Delta y$ - the GDP per capita growth;

inst - state institution;

$A_{0} D_{t}-$ a deterministic part (absolute coefficient, time trend);

$\alpha_{i}-$ a country fixed effect;

$\varepsilon, \mu-$ error terms.

Equation (2) is used to measure how much of the economic growth can be explained by the lagged values of economic growth, while equation (3), which is extension of equation (2), is constructed in order to test whether any new information about the economic growth volatility can be derived from the lagged values of particular indexes of state institutions. If no new information can be obtained from the lagged values of a particular index, then this index cannot be considered as a cause in the Granger sense of economic growth. On the other hand, when adding the lagged values of a particular index provides significantly new information about the economic growth volatility, then this index can be considered as a Granger cause of economic growth. Thus, the null hypotheses can be written as follows: $\beta_{1}=\beta_{2}=\ldots=\beta_{q}=0$, which according to the quoted definition means that a Granger causality relationship between state institutions cannot be confirmed.

In this research, we decided to conduct estimation for annual data. The estimates, due to a small number of observations, were conducted for one delay. The period of the analysis is 2006-2010.

For the estimations the system GMM estimator was chosen (Blundell \& Bond, 1998, pp. 115-143). For all calculations the two-step estimation with Windmeijer's (2005, pp. 25-51) correction was used. Variables were logarithmically transformed ${ }^{4}$.

${ }^{3}$ The applied procedure was proposed by M. Pilc in the article Piątek (2013, pp. 267288).

${ }^{4}$ Before the logarithmic transformation, all indexes of governance quality from 'Governance Matters' were increased by 10 in order to make them positive. 
The Granger causality was tested with the Wald test at a 5\% level of significance. For variables with a small number of observations, the following statistic, which has an F-distribution, was chosen:

$$
T_{W G}=\frac{T-k}{q} \cdot \frac{\hat{\sigma}^{2}\left(\varepsilon_{t}\right)-\hat{\sigma}^{2}\left(\mu_{t}\right)}{\hat{\sigma}^{2}\left(\mu_{t}\right)},
$$

where:

$\hat{\sigma}^{2}\left(\varepsilon_{t}\right)$ - the estimator of residual variance in equation (2);

$\hat{\sigma}^{2}\left(\mu_{t}\right)$ - the estimator of residual variance in equation (3);

$T$ - sample size;

$k$ - number of all independent variables used in equation (3).

If the calculated value of the statistic is greater than the critical one, there is a reason to reject the null hypothesis and to conclude about the existence of the Granger causality relationship between the analysed variables. In order to confirm $H_{1}$ adopted in this article, not only should the null hypothesis be rejected but also parameter $\beta$ should be less than zero for democracy and above zero for other state institutions. The results of the calculation are included in table 4 .

The obtained results confirm a surprising dependency between state institutions and the economic growth in the period of the financial crisis in transition countries. During the recession, in countries were before the crisis the institutions were worse, the pace of the economic growth was greater. Nevertheless, we need to exercise great caution while interpreting these results. The obtained results do not actually suggest that worse institutions cause faster economic growth; rather, they arise from the analysis ignoring a specific important factor.

Countries with worse institutions are at the same time less developed and less integrated with the EU. These factors should be taken into account in further research. Clearly, however, the results indicate that state institutions did not have a major impact on production change during the crisis.

\section{Relation between economic growth during financial crisis and institutional change during financial crisis}

In order to verify hypothesis $2\left(H_{2}\right)$ that the economic growth contributes to changes in state institutions in such a way that the faster the pace of growth the greater the improvement in state institutions a cross-sectional regression was used between the change in the indicator of selected state institutions in 2012 compared with 2006 as a dependent variable, and the average geometric growth in 2007-2010 as an explanatory variable. This relation is presented in chart 5 .

The data presented in chart 5 suggest that the relation between the economic growth and the change in institutions was in the period of the crisis positive; 
at least in relation to some of the institutions. A cross-sectional regression was conducted based on the following equation:

$$
\Delta \text { inst }=\alpha+\beta \cdot \Delta y+\varepsilon,
$$

where:

sinst - for the change in institutions between 2006-2012;

$\alpha, \beta$ - estimated parameters;

$\Delta y$ — the average GDP per capita growth in 2007-2010;

$\varepsilon$ - error term.

The results of these calculations are included in table 5.

The presented results confirm hypothesis $2\left(\mathrm{H}_{2}\right)$ in relation to Political Stability and Absence of Violence/Terrorism (PS) and Regulatory Quality (RQ). In relation to the remaining state institutions, the obtained parameters $\beta$ are consistent with expectations but not statistically significant.

In order to confirm the obtained results, a Granger causality test was conducted. In this model the following null hypothesis is tested: that the GDP growth was not the cause in the Granger sense of changes of state institutions in post-socialist countries during the financial crisis period.

The verification of this hypothesis was based on the set of the following two equations:

$$
\begin{aligned}
& \Delta \text { inst }_{i, t}=A_{0} D_{t}+\sum_{j=1}^{q} \gamma_{j} \Delta \text { inst }_{i, t-j}+\alpha_{i}+\varepsilon_{i, t}, \\
& \Delta \text { inst }_{i, t}=A_{0} D_{t}+\sum_{j=1}^{q} \gamma_{j} \Delta \text { inst } t_{i, t-j}+\sum_{j=1}^{q} \beta_{j} \Delta y_{i, t-j}+\alpha_{i}+\mu_{i, t},
\end{aligned}
$$

where:

$i$ - country;

$t$ - time;

$\Delta$ inst - change of state institution;

$\Delta y$ - the GDP per capita growth;

$A_{0} D_{0}$ - a deterministic part (absolute coefficient, time trend);

$\alpha_{i}-$ a country fixed effect;

$\varepsilon, \mu$ - error terms.

In this study it was decided to conduct estimation for three-year average. Due to a small number of observations only one delay (value $\mathrm{q}=1$ ) was used.

For the estimations the system GMM estimator was chosen (Blundell \& Bond, 1998, pp. 115-143). For all calculations the two-step estimation with Windmeijer's (2005, pp. 25-51) correction was used. Variables were logarithmically transformed 5 .

5 Before the logarithmic transformation all indicators of change of state institutions were increased by 10 in order to make them positive. 
The Granger causality was tested with the Wald test at the 5\% level of significance. For variables with a small number of observations the following statistic, which has an F-distribution, was chosen:

$$
T_{W G}=\frac{T-k}{q} \cdot \frac{\hat{\sigma}^{2}\left(\varepsilon_{t}\right)-\hat{\sigma}^{2}\left(\mu_{t}\right)}{\hat{\sigma}^{2}\left(\mu_{t}\right)},
$$

where:

$\hat{\sigma}^{2}\left(\varepsilon_{t}\right)$ - the estimator of residual variance in equation (6);

$\hat{\sigma}^{2}\left(\mu_{t}\right)$ - the estimator of residual variance in equation (7);

$T$ - sample size;

$k$ - number of all independent variables used in equation (7).

If the calculated value of the statistic is greater than the critical one, there is a reason to reject the null hypothesis and to conclude about the existence of the Granger causality relationship between the analysed variables. In order to confirm $\mathrm{H}_{2}$ adopted in this article, we need to not only reject the null hypothesis but also parameter $\beta$ should be less than zero for democracy and greater than zero for the remaining state institutions. The results of the calculation are included in table 6.

Although the obtained results do not allow us to accept $H_{2}$, the obtained parameters $\beta$ are consistent with the expectations in all cases apart from FHFR and CC. Unfortunately, it was impossible to reject the null hypothesis about parameters $\beta$ being statistically insignificant different from zero.

\section{Conclusion}

The aim of this paper was to analyse the relationships between state institutions and economic growth in 25 transition countries during the financial crisis of 2007-2010. For this purpose, two hypotheses were tested. Hypothesis 1: quality of state institutions from before have a positive impact on the economic growth during the crisis. Hypothesis 2: the economic growth influences the change in state institutions in such a way that the faster the pace of the economic growth the faster the improvement of state institutions, whereas a slow economic growth (a recession) may lead to the deterioration of these institutions.

The obtained results indicate that hypothesis 1 should be rejected. Nevertheless, the results must be interpreted with caution, as in the light of the relevant literature and the experiences of transition countries, it would be difficult to accept that worse institutions cause faster economic growth. The obtained result is rather the effect of the analysis not taking into account other factors significantly influencing the depth of the crisis in transition countries, such as a country's close financial and economic ties with other EU countries and the existence of natural resources (crude oil and natural gas) in a given country. Countries with worse state institutions are also less developed and less integrated with the EU, but many of them are rich in natural energy resources. These factors 
must be taken into account in further research. It would also seem justified to test hypothesis 1 for EU countries, especially that transition countries with good state institutions are all EU members.

The presented results do not confirm also hypothesis 2 . The obtained estimates of parameters were in line with the expectations but statistically insignificant. This may stem from a relatively short period of analysis, as well as from the fact that such countries as Belarus, Turkmenistan and Uzbekistan are authoritarian and seek to introduce neither market economy nor democracy (Hare \& Turley, 2013, p. 3), so the pace of the economic growth in those countries does not exercise there a significant influence on institutional changes. Also in relation to hypothesis 2, it would be interesting to test in for EU countries only.

\section{References}

Blundell, R., \& Bond, S. (1998). Initial conditions and moment restrictions in dynamic panel data models. Journal of Econometrics, 87(1). doi:10.1016/ s0304-4076(98)00009-8.

Granger, C.W.J. (1969). Investigating Causal Relations by Econometric Models and Cross-spectral Methods. Econometrica, 37(3). doi:10.2307/1912791.

Hare, P., \& Turley, G. (2013). Introduction to the Handbook. In P. Hare, \& G. Turley (Eds.), Handbook of the Economics and Political Economy of Transition. London-New York: Routledge.

Piątek, D., Szarzec, K., \& Pilc, M. (2013). Economic freedom, democracy and economic growth: a causal investigation in transition countries. Post-Communist Economies, 25(3). doi:10.1080/14631377.2013.813137.

Schweickert, R., Melnykovska, I., Gawrich, A., \& Drautzburg, T. (2008). Institutional Convergence of CIS Towards European Benchmarks. CASE Network Reports, 82.

Windmeijer, F. (2005). A finite sample correction for the variance of linear efficient two-step GMM estimators. Journal of Econometrics, 126(1). doi:10.1016/j. jeconom.2004.02.005.

\section{Acknowledgements}

Author contributions: author have given approval to the final version of the article.

Supplementary information: this research was conducted during author's stay at the Dekaban-Liddle Senior Fellowship, at the University of Glasgow, Scotland, during the spring semester 2014.

Note: the results of this study were presented at 26th Annual Conference of the European Association for Evolutionary Political Economy (EAEPE) held in Nicosia (Cyprus), 6-8 November 2014. 


\section{Appendix}

Table 1 .

Variables and their sources

\begin{tabular}{|c|c|c|}
\hline Variable & Short description & Source \\
\hline$\Delta \mathrm{y}$ & Yearly change in real GDP per capita & World Development Indicators, World Bank \\
\hline FHFR & $\begin{array}{c}\text { Average of Political Rights index and Civil Liber- } \\
\text { ties index }(1-7)\end{array}$ & $\begin{array}{c}\text { Freedom in the World, Freedom House Organ- } \\
\text { ization }\end{array}$ \\
\hline IEF & Overall Score (0-100) & Index of Economic Freedom, Heritage Foundation \\
\hline VA & Voice and Accountability $((-2.5)-2.5)$ & \\
\hline PS & $\begin{array}{l}\text { Political Stability and Absence of Violence/Terror- } \\
\qquad \text { ism }((-2.5)-2.5)\end{array}$ & \\
\hline GE & Government Effectiveness ((-2.5)-2.5) & Worldwide Government Indicators, World Bank \\
\hline RQ & Regulatory Quality ((-2.5)-2.5) & \\
\hline RL & Rule of Law ((-2.5)-2.5) & \\
\hline CC & Control of Corruption $((-2.5)-2.5)$ & \\
\hline
\end{tabular}

Source: own preparation.

Table 2.

\section{Descriptive statistics}

\begin{tabular}{crrrrrrrr}
\hline Variable & Observations & Mean & Standard deviation & Minimum & Q1 & Median & Q3 & Maximum \\
\hline$\Delta y$ & 150 & 1.033 & 0.058 & 0.825 & 1.011 & 1.038 & 1.066 & 1.236 \\
FHFR & 275 & 3.313 & 2.053 & 1.000 & 1.500 & 3,000 & 5.500 & 7.000 \\
IEF & 275 & 59.647 & 8.776 & 38.300 & 53.15 & 60.200 & 66.700 & 78.000 \\
VA & 275 & -0.126 & 0.999 & -2.210 & $-1,000$ & 0.032 & 0.859 & 1.157 \\
PS & 275 & 0.027 & 0.739 & -1.973 & -0.524 & 0.149 & 0.632 & 1.206 \\
GE & 275 & -0.094 & 0.756 & -1.676 & -0.694 & -0.229 & 0.652 & 1.190 \\
RQ & 275 & 0.073 & 0.915 & -2.176 & -0.464 & 0.223 & 0.924 & 1.427 \\
RL & 275 & -0.241 & 0.787 & -1.585 & -0.863 & -0.369 & 0.567 & 1.163 \\
CC & 275 & -0.344 & 0.663 & -1.495 & -0.934 & -0.489 & 0.229 & 1.024 \\
\hline
\end{tabular}

Source: own calculations. 
Table 3.

Results of cross-sectional regression between economic growth and state institutions

\begin{tabular}{|c|c|c|c|c|}
\hline State institution & Alpha & Beta & $\mathrm{R}^{2}$ & $\mathrm{H}_{1}$ \\
\hline FHFR & $\begin{array}{l}-0.009 \\
(-1.07)\end{array}$ & $\begin{array}{c}0.011^{* * *} \\
(5.12)\end{array}$ & 0.52 & rejected \\
\hline IEF & $\begin{array}{c}0.170^{* * *} \\
(5.81)\end{array}$ & $\begin{array}{c}-0.002^{* *} \\
(-5.23)\end{array}$ & 0.40 & rejected \\
\hline VA & $\begin{array}{c}0.025^{* * *} \\
(5.55)\end{array}$ & $\begin{array}{c}-0.024^{* * *} \\
(-5.59)\end{array}$ & 0.54 & rejected \\
\hline PS & $\begin{array}{c}0.027^{* * *} \\
(4.96)\end{array}$ & $\begin{array}{c}-0.023^{* * *} \\
(-3.87)\end{array}$ & 0.33 & rejected \\
\hline GE & $\begin{array}{c}0.024^{* * *} \\
(5.30)\end{array}$ & $\begin{array}{c}-0.031^{* * *} \\
(-5.53)\end{array}$ & 0.54 & rejected \\
\hline RQ & $\begin{array}{c}0.028^{* * *} \\
(6.38)\end{array}$ & $\begin{array}{c}-0.026^{* * *} \\
(-6.52)\end{array}$ & 0.56 & rejected \\
\hline RL & $\begin{array}{c}0.019^{* * *} \\
(4.05)\end{array}$ & $\begin{array}{c}-0.030^{* * *} \\
(-5.42)\end{array}$ & 0.51 & rejected \\
\hline $\mathrm{CC}$ & $\begin{array}{c}0.016^{* *} \\
(3.43)\end{array}$ & $\begin{array}{c}-0.034^{* * *} \\
(-4.85) \\
\end{array}$ & 0.49 & rejected \\
\hline
\end{tabular}

***, **, * mean the following levels of significance: $99 \%, 95 \%$ and $90 \%$, the value of $t$ statistics in parentheses.

Source: own calculations.

\section{Table 4.}

Results of the Wald tests for the null hypothesis: analysed institution is not a cause of the GDP growth in the Granger sense

\begin{tabular}{crrrrl}
\hline State institution & Observations & Empirical value & \multicolumn{1}{c}{ Critical value } & \multicolumn{1}{c}{ Beta } & $\mathrm{H}_{1}$ \\
\hline FHFR & 100 & 4.834 & 3.939 & $0.019^{* * *}$ & rejected \\
IEF & 100 & 6.206 & 3.939 & $-0.142^{* * *}$ & rejected \\
VA & 100 & 7.377 & 3.939 & $-0.166^{* * *}$ & rejected \\
PS & 100 & 4.180 & 3.939 & $-0.248^{* * *}$ & rejected \\
GE & 100 & 7.136 & 3.939 & $-0.246^{* * *}$ & rejected \\
RQ & 100 & 9.349 & 3.939 & $-0.223^{* * *}$ & rejected \\
RL & 100 & 9.024 & 3.939 & $-0.246^{* * *}$ & rejected \\
CC & 100 & 5.261 & 3.939 & $-0.223^{* * *}$ & rejected \\
\hline
\end{tabular}

Tests where the empirical value was greater than the critical one (which allows to reject the null hypothesis and conclude about the existence of the Granger causality) are in bold. ${ }^{* * *}{ }^{* *},{ }^{*}$ denote the following levels of significance: $99 \%, 95 \%$ and $90 \%$.

Source: own calculations. 
Table 5.

Results of cross-sectional regression between state institutions and economic growth

\begin{tabular}{|c|c|c|c|c|}
\hline State institution & Alpha & Beta & $\mathrm{R}^{2}$ & $\mathrm{H}_{2}$ \\
\hline FHFR & $\begin{array}{c}0.239^{*} \\
(1.91)\end{array}$ & $\begin{array}{l}-3.506 \\
(-1.53)\end{array}$ & 0.10 & rejected \\
\hline IEF & $\begin{array}{l}0.631 \\
(0.58)\end{array}$ & $\begin{array}{c}22.888 \\
(1.09)\end{array}$ & 0.03 & rejected \\
\hline VA & $\begin{array}{c}-0.045 \\
(-1.12)\end{array}$ & $\begin{array}{l}1.071 \\
(1.13)\end{array}$ & 0.05 & rejected \\
\hline PS & $\begin{array}{c}-0.048 \\
(-1.01)\end{array}$ & $\begin{array}{c}7.26^{* * *} \\
(3.60)\end{array}$ & 0.37 & accepted \\
\hline GE & $\begin{array}{l}0.031 \\
(0.63)\end{array}$ & $\begin{array}{l}2.005 \\
(1.47)\end{array}$ & 0.11 & rejected \\
\hline RQ & $\begin{array}{l}0.044 \\
(1.00)\end{array}$ & $\begin{array}{c}2.255^{*} \\
(1.75)\end{array}$ & 0.11 & accepted \\
\hline RL & $\begin{array}{c}0.098^{* *} \\
(2.07)\end{array}$ & $\begin{array}{l}1.348 \\
(1.17)\end{array}$ & 0.07 & rejected \\
\hline $\mathrm{CC}$ & $\begin{array}{l}-0.072 \\
(-1.47) \\
\end{array}$ & $\begin{array}{l}1.525 \\
(1.35) \\
\end{array}$ & 0.05 & rejected \\
\hline
\end{tabular}

***, **, * mean the following levels of significance: $99 \%, 95 \%$ and $90 \%$, the value of $t$ statistics in parentheses.

Source: own calculations.

Table 6.

Results of the Wald tests for the null hypothesis: the GDP growth is not a cause of change of analysed institution in the Granger sense

\begin{tabular}{cccccc}
\hline State institution & Observations & Empirical value & Critical value & Beta & $\mathrm{H}_{1}$ \\
\hline FHFR & 100 & -1.493 & 3.939 & 0.022 & rejected \\
IEF & 100 & 1.1872 & 3.939 & $0.297^{*}$ & rejected \\
VA & 100 & -1.022 & 3.939 & 0.002 & rejected \\
PS & 100 & -1.289 & 3.939 & 0.012 & rejected \\
GE & 100 & 2.215 & 3.939 & 0.023 & rejected \\
RQ & 100 & 0.489 & 3.939 & 0.005 & rejected \\
RL & 100 & 2.362 & 3.939 & $0.015^{* *}$ & rejected \\
CC & 100 & -0.705 & 3.939 & -0.012 & rejected \\
\hline
\end{tabular}

Tests where the empirical value was greater than the critical one (which allows to reject the null hypothesis and conclude about the existence of the Granger causality) are in bold. ${ }^{* * *}{ }^{* *},{ }^{*}$ denote the following levels of significance: $99 \%, 95 \%$ and $90 \%$.

Source: own calculations. 
Chart 1. Dendrogram of the transition countries in terms of institutions of state in 2002-2006

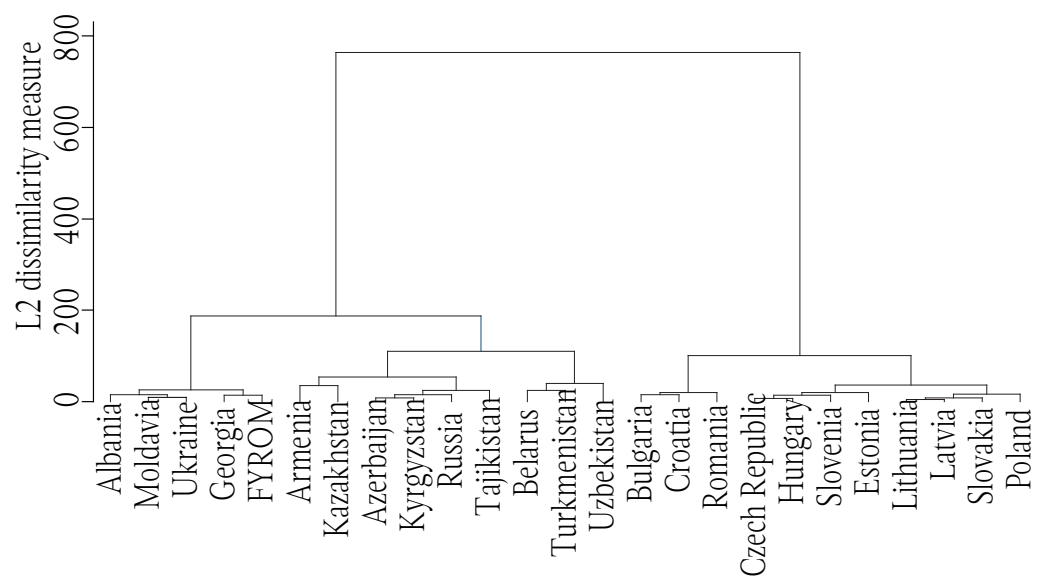

Source: own preparation.

Chart 2. GDP per capita in 2007-2012 (2006=1)

Countries with good institutions

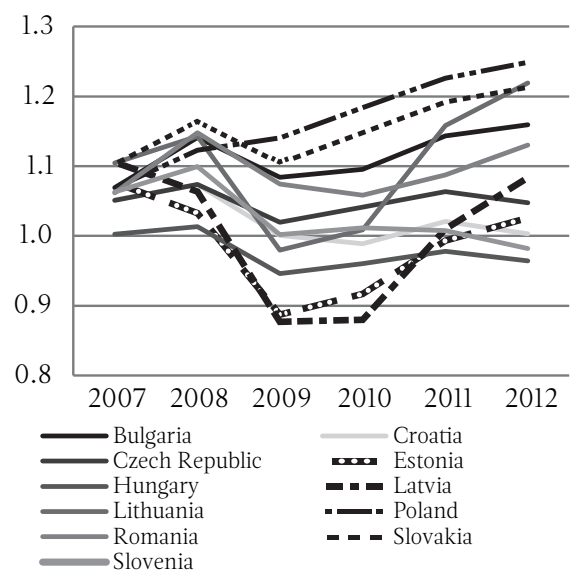

Countries with good institutions

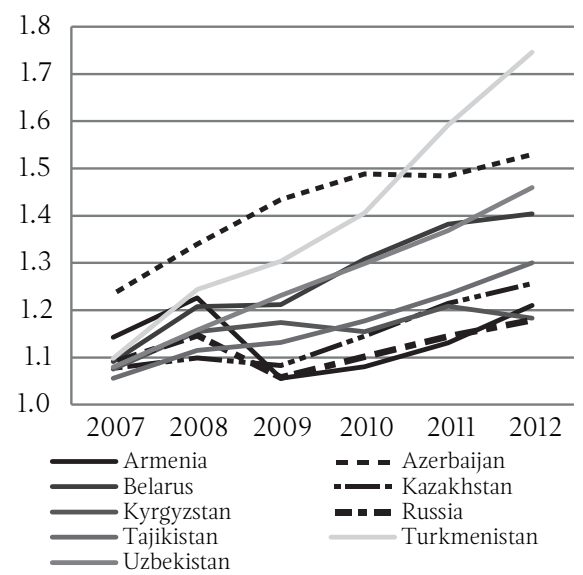


Countries with not so good state institutions

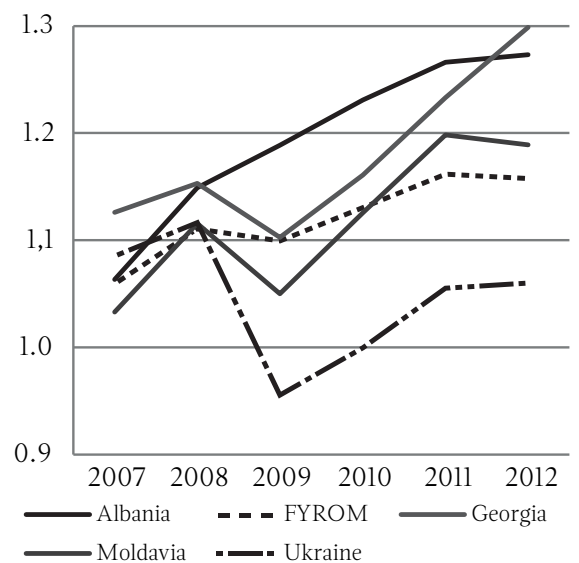

Average

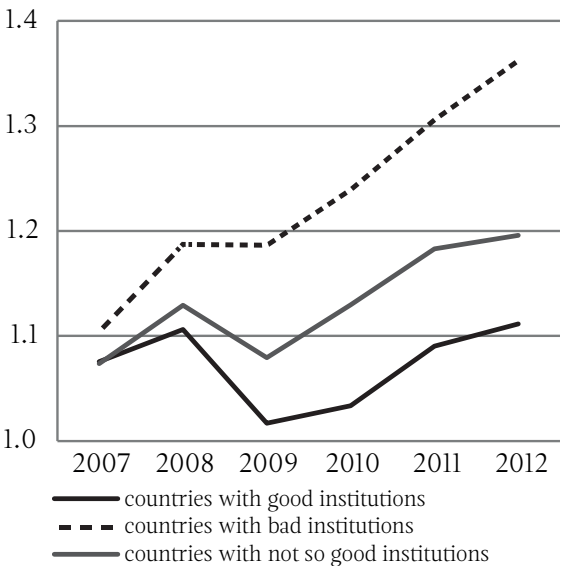

Source: own preparation.

\section{Chart 3. Changes of the institutions in 2007-2012}

Average change of FHRF

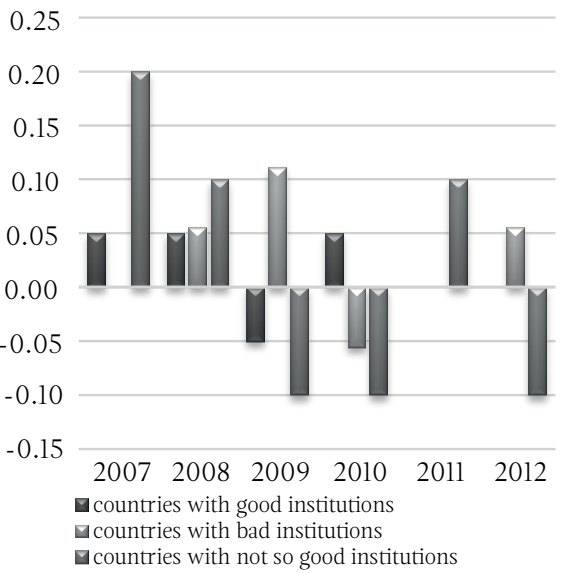

Average change of IEF

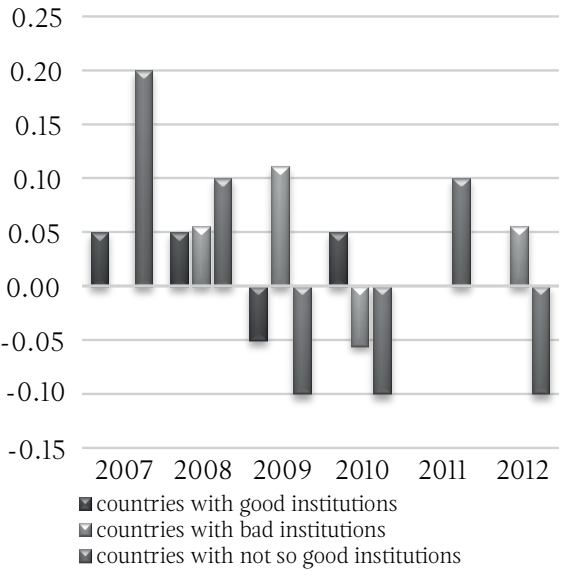


Average change of VA

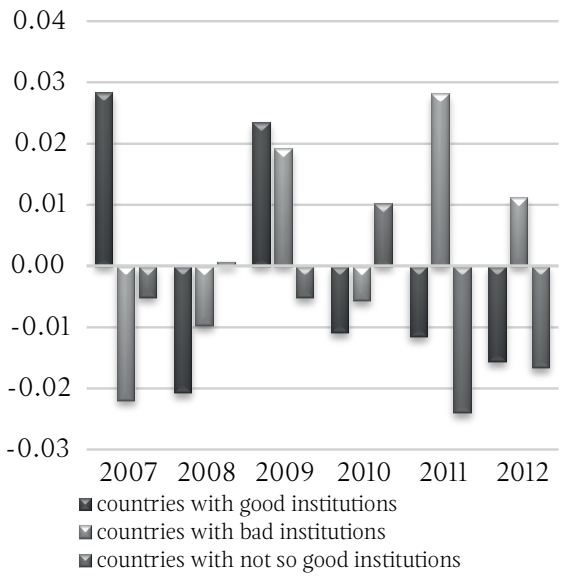

Average change of GE

0.10

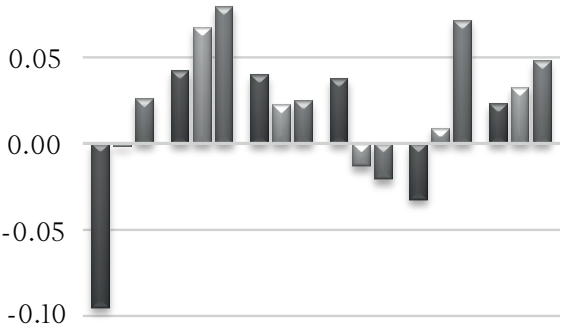

$\begin{array}{lllllll}-0.15 & 2007 & 2008 & 2009 & 2010 & 2011 & 2012\end{array}$

口 countries with good institutions

$\square$ countries with bad institutions

@ countries with not so good institutions
Average change of PS

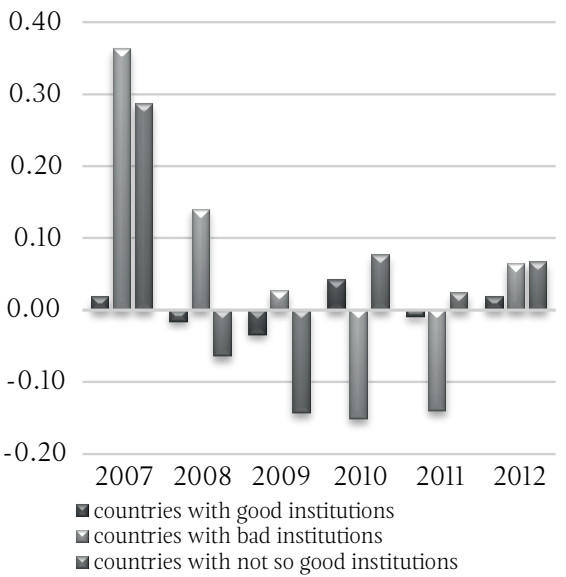

Average change of RQ

0.20

0.15

0.10

0.05

0.00

$-0.05$

$20072008200920102011 \quad 2012$

a countries with good institutions

$\square$ countries with bad institutions

$\square$ countries with not so good institutions 
Average change of RL

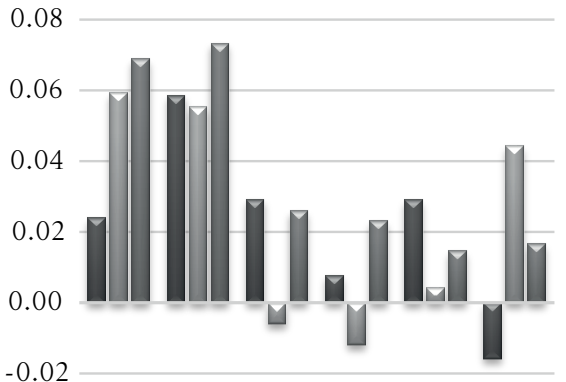

$-0.04$ $20072008200920102011 \quad 2012$

a countries with good institutions $\square$ countries with bad institutions

घcountries with not so good institutions
Average change of CC

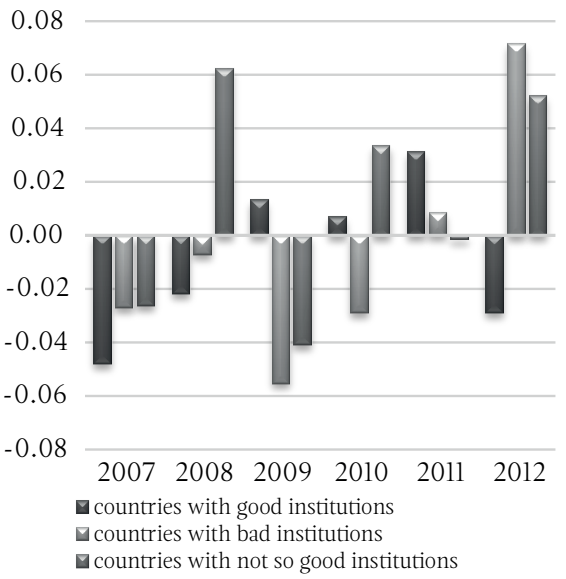

Source: own preparation.

Chart 4. Economic growth (average growth rate in 2007-2010) and state institutions (average index in 2002-2006) in transition countries

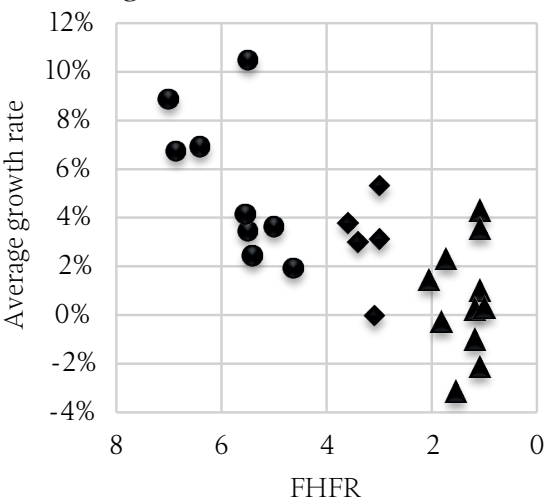

$\boldsymbol{\Delta}$ countries with good institutions - countries with bad institutions - countries with not so good institutions

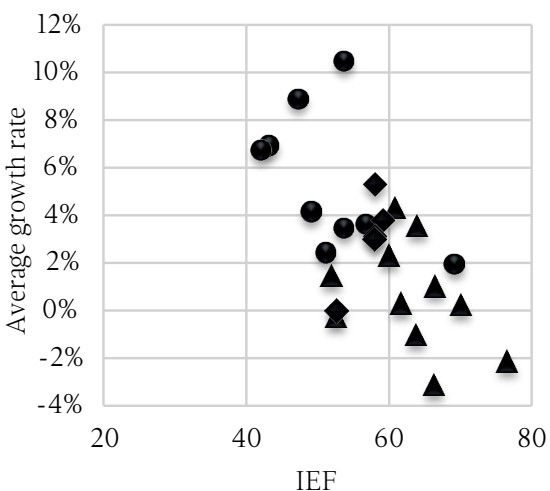

Acountries with good institutions

- countries with bad institutions

จ countries with not so good institutions 

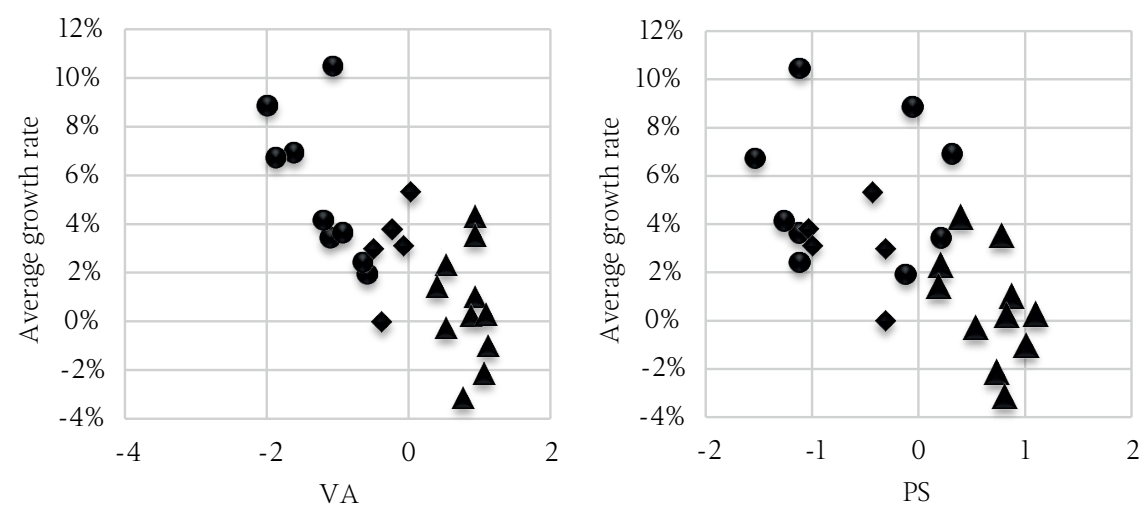

$\mathbf{A}$ countries with good institutions

- countries with bad institutions

$\checkmark$ countries with not so good institutions

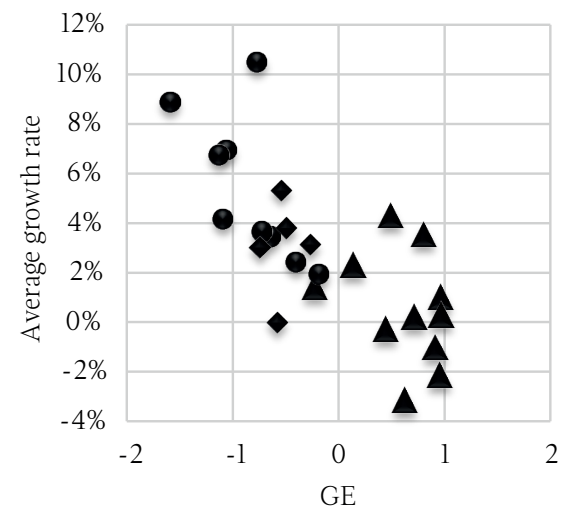

$\boldsymbol{\Delta}$ countries with good institutions

- countries with bad institutions

- countries with not so good institutions

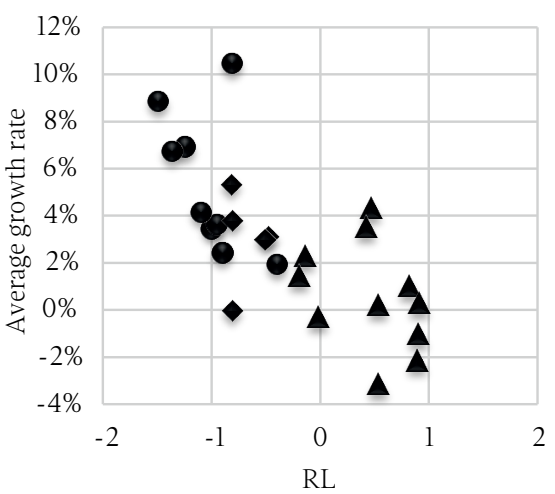

Acountries with good institutions

- countries with bad institutions

- countries with not so good institutions

$\boldsymbol{\Delta}$ countries with good institutions

- countries with bad institutions

- countries with not so good institutions

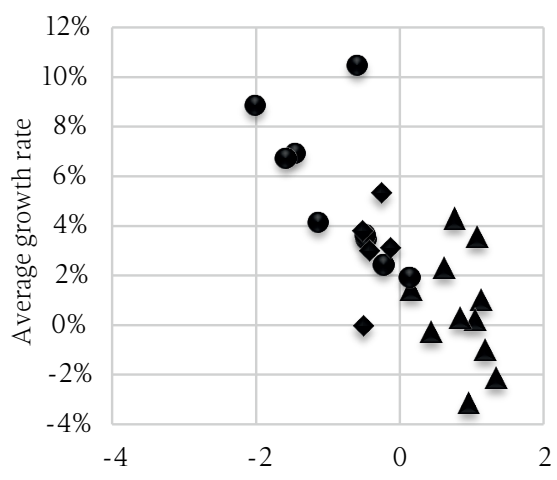

RQ

A countries with good institutions

- countries with bad institutions

- countries with not so good institutions

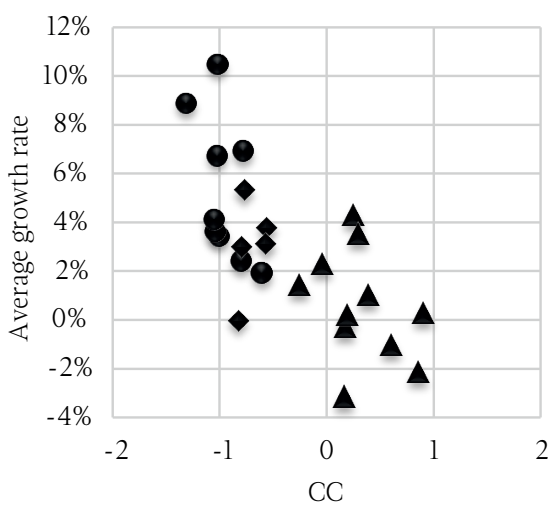

A countries with good institutions

- countries with bad institutions

- countries with not so good institutions

Source: own preparation. 
Chart 5. Change of state institutions (2006-2012) and economic growth (average growth rate in 2007-2010) in transition countries
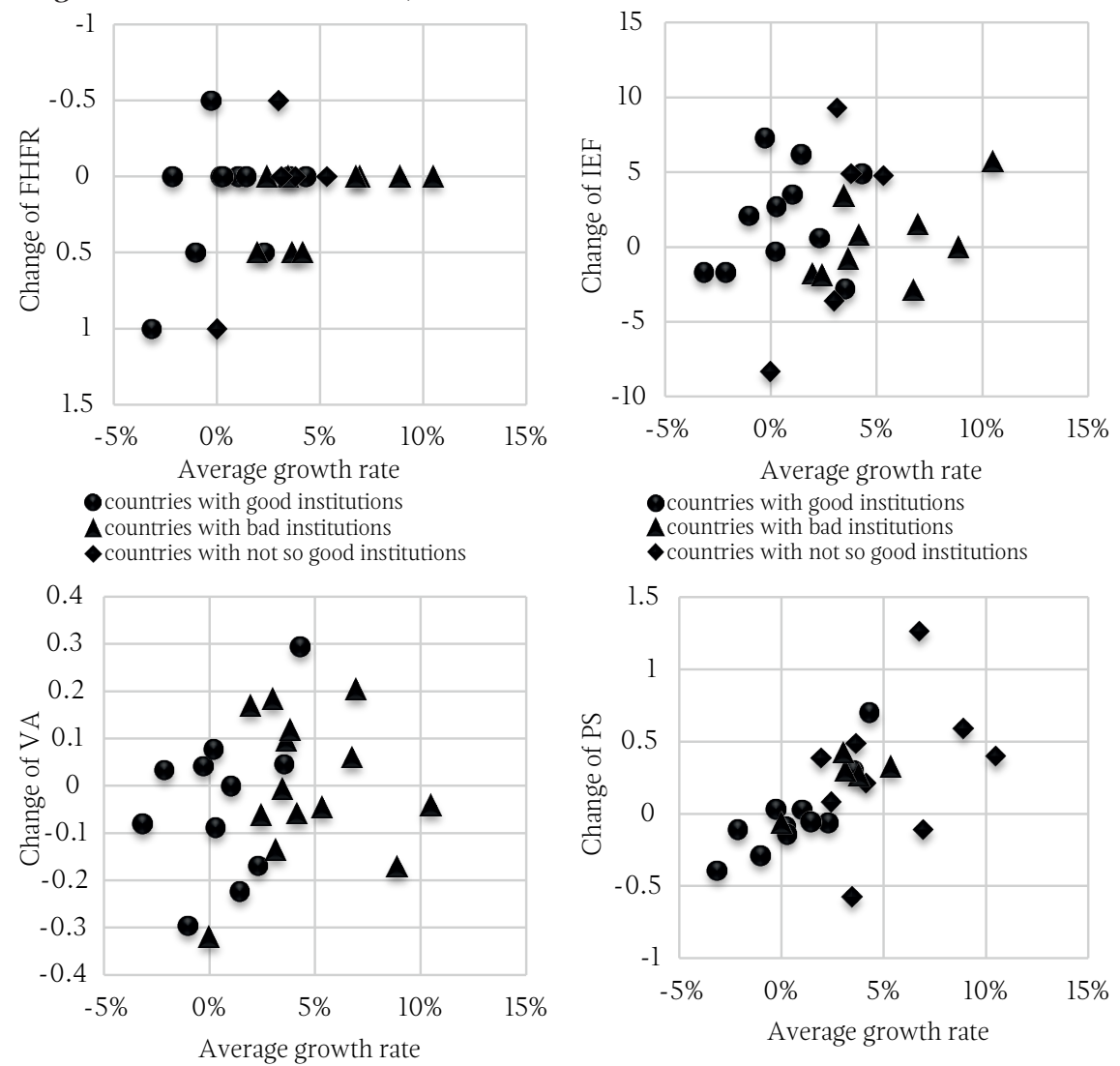

- countries with good institutions

A countries with bad institutions

$\diamond$ countries with not so good institutions

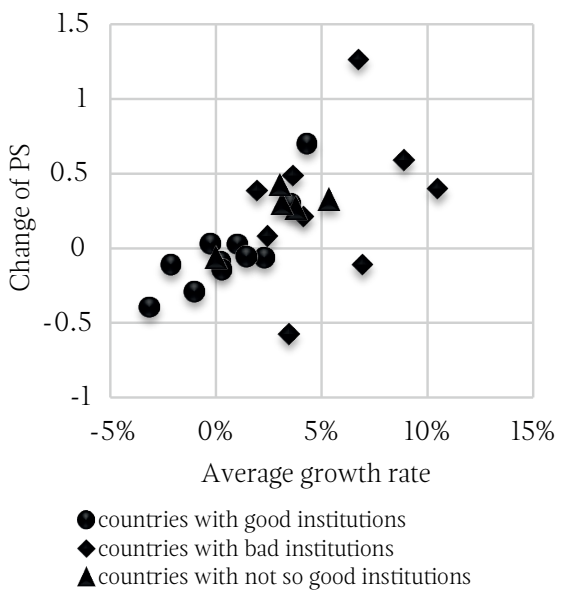

- countries with good institutions

$\boldsymbol{\Lambda}$ countries with bad institutions

$\boldsymbol{\Delta}$ countries with not so good institutions

countries with bad institutions

$\boldsymbol{\Delta}$ countries with not so good institutions 


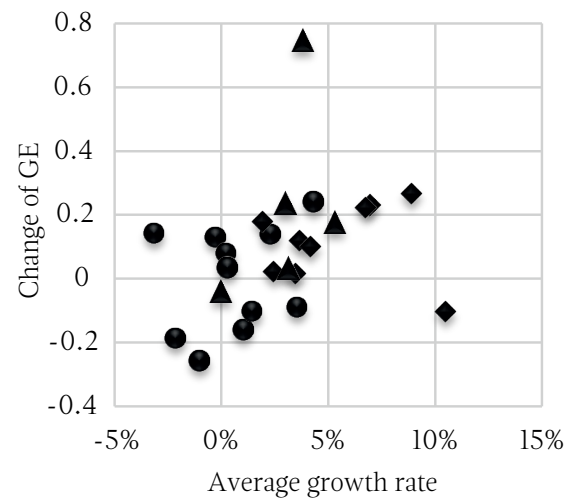

- countries with good institutions - countries with bad institutions

$\boldsymbol{\Delta}$ countries with not so good institutions

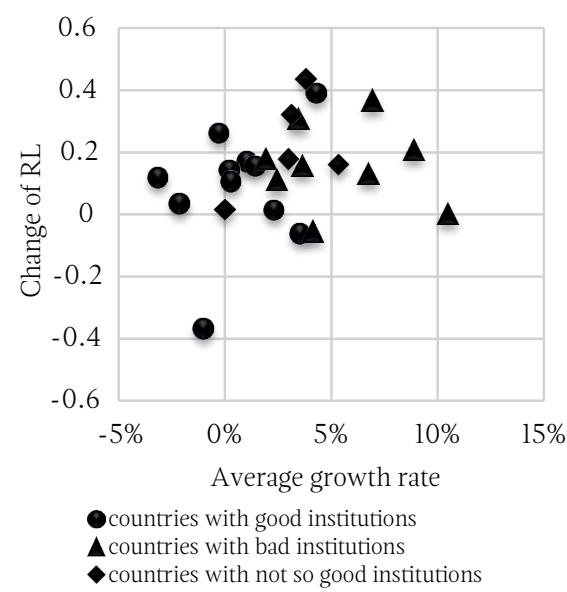

Source: own preparation.

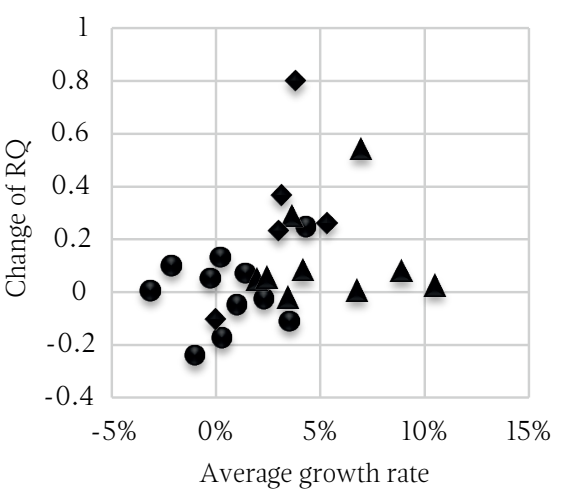

- countries with good institutions

$\boldsymbol{\Delta}$ countries with bad institutions

- countries with not so good institutions

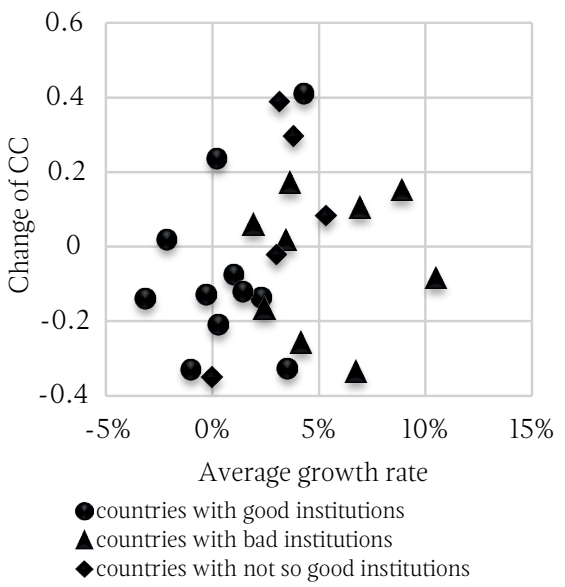


